\title{
Review
}

\section{Ayurveda and Traditional Chinese Medicine: A Comparative Overview}

\author{
Bhushan Patwardhan ${ }^{1}$, Dnyaneshwar Warude ${ }^{1}$, P. Pushpangadan ${ }^{2}$ and Narendra Bhatt ${ }^{3}$ \\ ${ }^{1}$ Interdisciplinary School of Health Sciences, University of Pune, Pune $411007,{ }^{2}$ National Botanical Research \\ Institute, Lucknow 226001 and ${ }^{3}$ Zandu Pharmaceutical Ltd, Mumbai 400 025, India
}

\begin{abstract}
Ayurveda, the traditional Indian medicine (TIM) and traditional Chinese medicine (TCM) remain the most ancient yet living traditions. There has been increased global interest in traditional medicine. Efforts to monitor and regulate herbal drugs and traditional medicine are underway. China has been successful in promoting its therapies with more research and science-based approach, while Ayurveda still needs more extensive scientific research and evidence base. This review gives an overview of basic principles and commonalities of TIM and TCM and discusses key determinants of success, which these great traditions need to address to compete in global markets.
\end{abstract}

Keywords: Ayurveda - Chinese medicine - complementary and alternative medicine traditional medicine

\section{Introduction}

Ayurveda, the traditional Indian medicine (TIM) and traditional Chinese medicine (TCM) remain the most ancient yet living traditions. These are the two 'great traditions' with sound philosophical, experiential and experimental basis. Increased side effects, lack of curative treatment for several chronic diseases, high cost of new drugs, microbial resistance and emerging diseases are some reasons for renewed public interest in complementary and alternative medicines (1). It has been postulated that by 2010 at least two-thirds of the United States population will be using one or more of the alternative therapeutic approaches. Use of indigenous drugs of natural origin forms a major part of such therapies; more than 1500 herbals are sold as dietary supplements or ethnic traditional medicines (2). Pharmaceutical companies have renewed their strategies in favor of natural product drug development and discovery (3). For instance, in Europe, AnalytiCon Discovery has stressed on drug discovery based on natural product chemistry (4). In the Asia-Pacific region, MerLion Pharmaceuticals in Singapore has comprehensive

For reprints and all correspondence: Bhushan Patwardhan, $\mathrm{PhD}$,

Interdisciplinary School of Health Sciences, University of Pune,

Pune 411 007, India. Tel/Fax: +91-20-25691758;

E-mail: bhushan@unipune.ernet.in structures and capabilities necessary for natural productbased drug discovery (5). China has successfully promoted its own therapies over the globe with a science-based approach. Growing popularity of TCM can be evidenced by the rapid increase in number of licensed Chinese medicine providers in the United States. The Chinese government has pledged to create several export-oriented TCM giants in the coming years (6). Continuous efforts in promotion of the indigenous therapies by China have put TCM in a commendable position. Global acceptance of Ayurveda is gearing up and there has been a steep rise in the demand for medicinal plants from India (7). The Pharmaceutical Research and Development Committee report of Ministry of Chemicals, Government of India also underscores the importance of traditional knowledge (8). The increasing use of traditional therapies demands more scientifically sound evidence for the principles behind therapies and for effectiveness of medicines. Recent advancements in the analytical and biological sciences, along with innovations in genomics and proteomics can play an important role in validation of these therapies. Western scientific community views traditional medicines cautiously and stress the concerns related to research, development and quality $(9,10)$. This review delineates the challenges that TCM and TIM need to address to become more acceptable to the world community. 


\section{Global Markets, Regulations and Acceptance}

The global pharmaceutical market was worth US $\$ 550$ billion in 2004 (11) and is expected to exceed US $\$ 900$ billion by the year 2008. The herbal industry shares about US $\$ 62$ billion with good growth potential. The World Bank reports trade in medicinal plants, botanical drug products and raw materials is growing at an annual growth rate between 5 and 15\% (12). Within the European community, botanical medicine represents an important share of the pharmaceutical market (13); the nutraceutical sector is also growing rapidly. In 2001, US $\$ 17.8$ billion was spent in the United States on dietary supplements, US $\$ 4.2$ billion of it for botanical remedies (14). In India the value of botanicals related trade is about US $\$ 10$ billion per annum with annual export of US \$1.1 billion (15) while China's annual herbal drug production is worth US $\$ 48$ billion with export of US $\$ 3.6$ billion (16). Presently, the United States is the largest market for Indian botanical products accounting for about $50 \%$ of the total exports. Japan, Hong Kong, Korea and Singapore are the major importer of TCM taking 66\% share of China's botanical drugs export (17).

Globally, there have been concerted efforts to monitor quality and regulate the growing business of herbal drugs and traditional medicine. Health authorities and governments of various nations have taken an active interest in providing standardized botanical medications. United States Congress has fuelled rapid growth in the nutraceutical market with passage of the Dietary Supplement Health and Education Act in 1994. US Food and Drug Administration (FDA) has recently published the International Conference on Harmonization guidance Common Technical Document addressing concerns related to quality of medicines that also includes herbals (18). The National Center for Complementary and Alternative Medicine has been inaugurated as the United States Federal Government's lead agency for scientific research in this arena of medicine. Its mission is to explore complementary and alternative healing practices in the context of rigorous science, support sophisticated research, train researchers, disseminate information to the public on the modalities that work and explain the scientific rationale underlying discoveries. The center is committed to explore and fund all such therapies for which there is sufficient preliminary data, compelling public health need and ethical justifications $(19,20)$. World Health Organization (WHO) is keen regarding traditional medicine and has been active in creating strategies, guidelines and standards of botanical medicines (21). The global scenario illustrates vividly both promise and challenges presented by the traditional medicines. India needs to identify the extent to which Ayurvedic therapeutics is safe and effective so that it could get wide global acceptance.

\section{Basic Principles: TIM and TCM}

Ayurveda and TCM have many commonalities. The focus of both the systems is on the patient rather than disease. Both systems fundamentally aim to promote health and enhance the quality of life, with therapeutic strategies for treatment of specific diseases or symptoms in holistic fashion. Almost half of the botanical sources used as medicines have similarities; moreover, both systems have similar philosophies geared towards enabling classification of individuals, materials and diseases. TCM considers the human at the center of the universe as an antenna between celestial and earthly elements. Water, earth, metal, wood and fire are the five elements of the material world. The world is a single unit and its movement gives rise to yin and yang, the two main antithetic aspects. The actual meaning of the term yin and yang is 'opposites', such as the positive and the negative. However, Chinese believe that yin and yang is not absolute but relative. Consistent with the modern view of homeostasis, yin and yang are interchanged to meet the view that 'yang declines and yin rises' or 'yang is raised to produce a decline of yin'. The four bodily humors (qi, blood, moisture and essence) and internal organ systems (zang fu) play an important role in balancing the yin and yang in human body. Proper formation, maintenance and circulation of these energies are essential for health. When the two energies fall out of harmony, disease develops. The physician takes into account this concept while treating patients. Drugs or herbs are used to correct this imbalance of yin-yang in the human body $(22,23)$.

Ayurveda considers that the universe is made up of combinations of the five elements (pancha mahabhutas). These are akasha (ether), vayu (air), teja (fire), aap (water) and prithvi (earth). The five elements can be seen to exist in the material universe at all scales of life and in both organic and inorganic things. In biological system, such as humans, elements are coded into three forces, which govern all life processes. These three forces (kapha, pitta and vata) are known as the three doshas or simply the tridosha. Each of the doshas is composed of one or two elements. Vata is composed of space and air, Pitta of fire, and kapha of water and earth. Vata dosha has the mobility and quickness of space and air; pitta dosha the metabolic qualities of fire; kapha dosha the stability and solidity of water and earth. The tridosha regulates every physiological and psychological process in the living organism. The interplay among them determines the qualities and conditions of the individual. A harmonious state of the three doshas creates balance and health; an imbalance, which might be an excess (vriddhi) or deficiency (kshaya), manifests as a sign or symptom of disease $(24,25)$ (Figs 1 and 2).

\section{Determinants of Success}

\section{Quality of the Botanical Drugs}

Consistency in composition and biological activity are essential requirements for the safe and effective use of therapeutic agents. Quality is the critical determinant of safety and efficacy of botanical medicines; however, botanical preparations rarely meet the standards of quality, which refers to procedures and markers for assessing and verifying the strength of botanical raw materials or extracts or formulations thereof (26). 


\section{Basic principles of TCM}

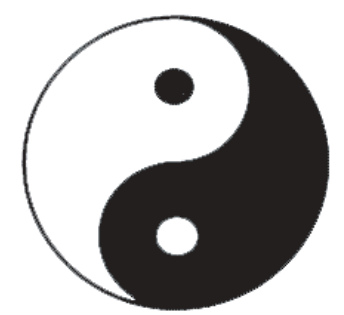

Symbol for yin and yang

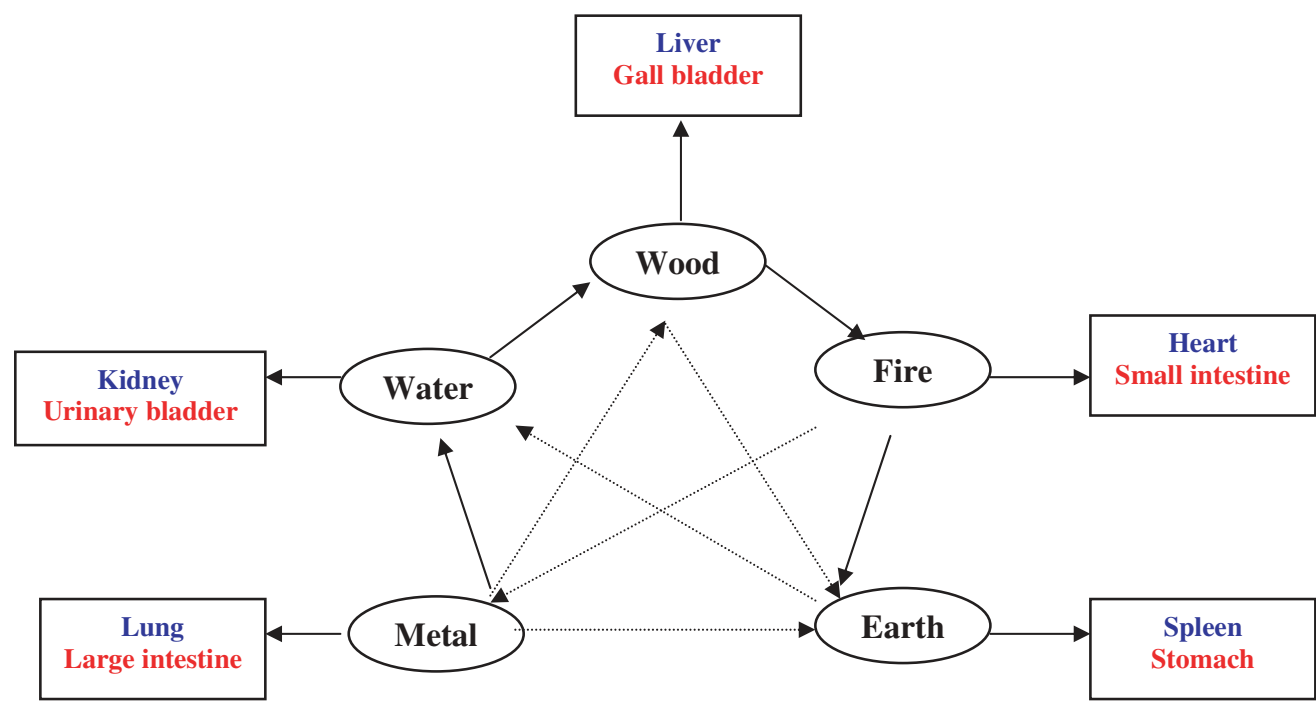

$\longrightarrow$ Mutual nourishment cycle

- Zang organs

$\rightarrow$ Mutual restraint cycle

- Fu organs

Figure 1. Basic principles of TCM.

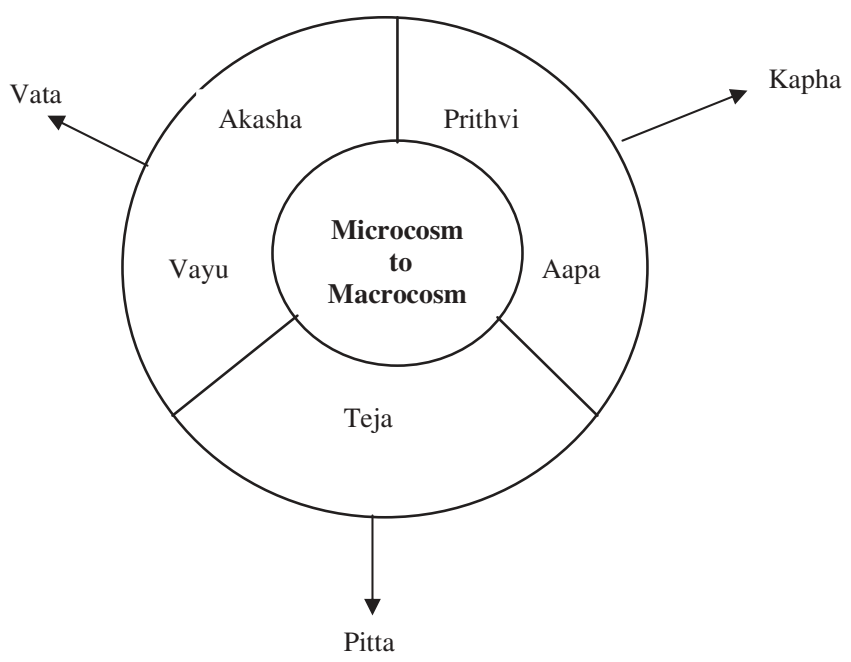

Figure 2. Basic principles of TIM: relation of pancha mahabhutas and tridosha.
Chromatographic techniques and chemical marker assisted characterization of the botanicals does not ensure consistent biological activity or stability (27). Therefore, production of quality botanical medicines has become a challenge to regulatory authorities, scientific organizations and manufacturers. WHO (28), USFDA (29), European Scientific Cooperative on Phytomedicine (ESCOP) (30) have published standard sets of guidelines to address the concerns. Some of the progressive manufacturers follow them to provide standardized botanical medicine. In India, about 9000 licensed units manufacture traditional medicines with or without proper standardization (31). Indian manufacturers generally follow WHO guidelines for quality control. Adulteration of market samples remains a major problem in domestic and export markets of Indian herbal products. Chemical analysis of some antiarthritic medicines from Ayurveda has led to a finding that synthetic anti-inflammatory drugs like phenylbutazone, indomethacin and/or corticosteroids have been added (32). Heavy metals 
such as mercury, arsenic and lead contamination has also become a critical problem $(33,34)$. Market botanicals are stored under undesirable conditions over the years and may have contamination or adulteration of other materials, which thereby adversely affect the efficacy and sometimes even add to toxicity. Lack of proper processing of the materials even by pharmaceutical firms contributes to decline of the herbal business. Availability of the desired genotype of plant in the required quantity, free from toxic contaminants and with desired therapeutic activity have also become a critical issue (35). China has successfully overcome such difficulties by modernizing its traditional medicine profession with government-sponsored Good Agricultural Policies (GAPs) and Good Manufacturing Practices (GMPs). GAPs stresses selection of the correct germplasm with high content of stable active components. The cultivation practices offer Standard Operating Procedures for use of fertilizers, irrigation systems and disease management allied with insects and pest prevention and cure. GAPs also establish standards for noxious and harmful contaminants like heavy metals, pesticide residues and microbes in plants. All manufactures of TCM are mandated to comply with guidelines laid down by China's State Drug Administration (SDA) by 2004 and farms producing raw ingredients must comply with SDA-imposed standards by 2007. As a result, 1470 companies have qualified for GMPs while 570 failed to meet the standards (36). For marketing of herbal medicine in China, special requirements such as quality dossier, safety and efficacy evaluation and specific labeling criteria are required. New herbal drugs must be approved according to the Drug Administration Laws.

Similar integrated efforts are needed to raise the image of Ayurvedic medicines in the global business. Government of India has promulgated GMP regulations for traditional systems of medicines to improve the quality and standard of Ayurvedic, Siddha and Unani drugs in pharmacies. New rules delineating essential infrastructure, manpower and quality control requirements came into force from 2000 and form part of the Drugs and Cosmetics Act, 1940 (37). Licensing of Ayurvedic medicine is also governed under drug and cosmetics act, 1940. Ayurvedic Patent and Proprietary medicines need to contain only the ingredients mentioned in the recommended books as specified in the Act. For any new herbal medicine safety and efficacy data are mandatory. Depending on nature of herbs and market availability, different requirements exist for submission of clinical trial and safety data.

Standardization of herbal drugs is not just an analytical operation for identification and assay of active principles; rather, it comprises total information and controls to necessarily guarantee consistent composition of all herbals. A good example of this is a polyherbal formulation $\left(A r t r e x^{\circledR}\right)$ designed for the treatment of arthritis that contains four botanicals. The formulation, standardized using modern scientific tools and with known markers, has been granted a US patent (38). Validated agro-industrial technologies should be applied for cultivation and processing of medicinal plants and manufacturing of herbal medicines. Indian herbal drug industry needs to ensure procurement of standardized authentic raw material free from toxic contaminants. Improving processing technologies, conducting all operations under GMP compliance and maintenance of in-process quality control for manufacturing quality herbal products also need evidence for therapeutic efficacy, safety and shelf life. Such approaches remain important in global promotion of Ayurveda.

\section{Government Policies}

In China and India formal training is an integral part of the national health program, which helps in ensuring quality standards in health care delivery. China became successful in integrating TCM in the national health care system. Science-based approaches were utilized and inculcated in the education of TCM with emphasis on research. Hospitals practicing TCM treat more than 200 million outpatients and almost 3 million inpatients annually. About $95 \%$ of general hospitals in China have traditional medicine departments (39).

Government of India also has expressed support and encouragement for the TIM. A separate department for Indian Systems of Medicine and Homeopathy (ISM\&H) now known as AYUSH (Ayurveda, Yoga, Unani, Siddha, Homoeopathy) was established in March 1995 to promote indigenous systems. Priorities include education, standardization of drugs, enhancement of availability of raw materials, research and development, information, communication and larger involvement in the national system for delivering health care. The Central Council of Indian Medicine oversees teaching and training institutes while Central Council for Research in Ayurveda and Siddha deals with interdisciplinary research. Some TIM products are being added into family welfare programs of the government under the World Bank project. These medicines are mainly for common diseases like anemia, edema during pregnancy, postpartum problems such as pain, uterine and abdominal complications, difficulties with lactation, nutritional deficiencies and childhood diarrhea (40). The government has also established 10 new drug testing laboratories for TIM and is upgrading existing laboratories to provide documented high quality evidence to licensing authorities for the safety and quality of herbal medicines. This replaces the earlier ad hoc system of testing that was considered unreliable. In 2002, the Council for Scientific and Industrial Research has launched a research program under New Millennium Indian Technology Leadership Initiative scheme in Ayurveda identifying three disease areas such as arthritis, diabetes and hepatic disorders, which afflict large numbers of the Indian population.

Many additional concerns need to be addressed. The quality of education in many colleges needs to be improved. Under the pretext of integration, attempts to make hybrid curricula producing inadequately trained graduates remain unacceptable for either modern or traditional systems (41). A paucity of funds is noticeable; ISM\&H gets only $2 \%$ of the total health budget of the nation. A corrective and promotive policy needs to be initiated for TIM to fully realize its potential and 
contribute more meaningfully to integrative health services. The industry has not been able to grow and develop optimally during the last few decades. Largely, the achieved growth is owing to industry's own initiatives, in-house research and development. A national organization, Ayurvedic Drugs Manufacturers' Association is taking a proactive role to improve quality and research that needs to be nurtured, stimulated and sustained by providing special funding or incentives. Preparation of formularies and pharmacopoeial standards have been attempted but a lot remains to be done. Numbers of Indian botanical sources and their medicinal uses as in case of turmeric have been patented by claiming innovations that are already in the public domain. Necessary measures to protect such intellectual property are important as the retrieval and contesting of patents is a very costly and time-consuming affair (42). For this purpose, the Government of India has established a Traditional Knowledge Digital Library on traditional medicinal plants, which will also lead to a Traditional Knowledge Resource Classification (43). Linking this to internationally accepted International Patent Classification system will mean building the bridge between the knowledge contained in an old Sanskrit text and a patent examiner. This may control the problem of mistakingly granting patents since the examiner will know the Indian rights to that knowledge. It could integrate widely scattered and distributed references on TIM in retrievable form and will be a major impetus to modern research in the developing world.

\section{Research}

Natural products extracts of therapeutic relevance are of paramount importance as reservoirs of structural and chemical diversity. A recent review on national pharmacopoeias from several countries reveals at least 120 distinct chemical substances from different plants that have utility as lifesaving drugs (44). This has been achieved through chemical and pharmacological screening of only $6 \%$ of the total plant species. Untapped, hidden wealth in the flora needs to be unearthed and explored to cure diseases like AIDS, cancer, diabetes, etc. Recently, NIH has started extensive research for antiinflammatory compounds from turmeric, ginger and boswellia with the aid of Ayurvedic knowledge. Screening of different plants for novel anticancer compounds is also in progress with reference experiential data from traditional systems (45). Botanical immunodrugs from traditional medicine can provide newer opportunities to bioprospect diverse and synergistic chemical moieties, which in combination might act on multiple targets and improve the therapeutic spectrum (46). PUBMED, Google scholar and Science direct are the widely recognized web databases of scientific literature. We have given comparative citations for Indian and Chinese medicine using different key words and also provided the patent data of USPTO. Visibility of Ayurvedic medicine remains much lower as compared with TCM (Table 1).

Chinese medicine became successful in crossing philosophical barriers through constant reworking of the basic system.
Table 1. Citations and patent data for Indian and Chinese medicine (as on September 10, 2005)

\begin{tabular}{|c|c|c|c|c|}
\hline Database & $\begin{array}{l}\text { Key words: } \\
\text { TIM }\end{array}$ & $\begin{array}{l}\text { Citations/ } \\
\text { patents }\end{array}$ & $\begin{array}{l}\text { Key words: } \\
\text { TCM }\end{array}$ & $\begin{array}{l}\text { Citations/ } \\
\text { patents }\end{array}$ \\
\hline \multirow[t]{2}{*}{ PubMed } & $\begin{array}{l}\text { Ayurvedic } \\
\text { medicine }\end{array}$ & 1045 & $\begin{array}{l}\text { Chinese } \\
\text { medicine }\end{array}$ & 10278 \\
\hline & TIM & 361 & TCM & 6847 \\
\hline \multirow[t]{2}{*}{ Science Direct } & $\begin{array}{l}\text { Ayurvedic } \\
\text { medicine }\end{array}$ & 87 & $\begin{array}{l}\text { Chinese } \\
\text { medicine }\end{array}$ & 990 \\
\hline & TIM & 77 & $\mathrm{TCM}$ & 612 \\
\hline \multirow[t]{2}{*}{ Google scholar } & $\begin{array}{l}\text { Ayurvedic } \\
\text { medicine }\end{array}$ & 4220 & $\begin{array}{l}\text { Chinese } \\
\text { medicine }\end{array}$ & 476000 \\
\hline & TIM & 32900 & $\mathrm{TCM}$ & 68300 \\
\hline US patent granted & $\begin{array}{l}\text { Ayurvedic } \\
\text { medicine/TIM }\end{array}$ & 3 & $\begin{array}{l}\text { Chinese } \\
\text { medicine/TCM }\end{array}$ & 195 \\
\hline US patent filed & $\begin{array}{l}\text { Ayurvedic } \\
\text { medicine/TIM }\end{array}$ & 26 & $\begin{array}{l}\text { Chinese } \\
\text { medicine/TCM }\end{array}$ & 259 \\
\hline
\end{tabular}

The first compound derived from Chinese herbal remedies to enter the western market was ephedrine, an amphetaminelike stimulant from ma huang (Ephedra sinica). The next was artimisinin, a potent antimalarial from qinghao (Artemisia апnиa). In 2003, Chinese researchers launched a phase II trial to test the efficacy of a drug called kanglaite from iijen (Coix lachryma-jobi) for treating non-small-cell lung cancer (47). This is the first drug from TCM to enter clinical trials in the United States. Other drug molecules from TCM are xue baoPG2 (general tonic from Astragalus membracaceus) and camptothecin analogs as CPT11 and topotecan (anticancer from Camptotheca accuminata), which have a huge market. In 2002, 1141 different traditional plant drugs were registered for their therapeutic activities including several new single compounds from plants as arteannuin (antimalarial), indirubin (anticancer), etc. One of the twelve focal points in the current Five-Year Plan of China's Ministry of Science and Technology is to modernize research in TCM. Pharmacopoeia of the People's Republic of China (2000) (48) contains 992 monographs of Chinese crude drugs and traditional Chinese patent medicines in which 76 new admissions and 248 monographs have been revised. Controlled clinical trials have been initiated at several hospitals and research organizations to prove the efficacy and safety of the Chinese medicine (49,50). Recent reports on adverse effects of drug like ma huang (51) and gingko (52) have sounded a cautionary note that promoting traditional medicine from conception to commercialization will not be easy.

India has world-class expertise and facilities for organic synthesis, isolation and structure elucidation, biological screening, toxicological testing and pharmacokinetics. This is supplemented by the expertise for development of agrotechnology for cultivation of medicinal plants. Industry participation to ensure successful upscaling and implementation of technology is increasing. Generation of leads with structural diversities through creation of natural product libraries, identification of proper targets and their proper validation and optimization is of paramount importance (53). India has 
progressive research institutes like Central Drug Research Institute (CDRI), Central Institute of Medicinal and Aromatic Plants and National Botanical Research Institute at Lucknow, Regional Research Laboratories (RRL), at Jammu, Bhubaneshwar and Jorhat, National Chemical Laboratory at Pune, which routinely undertake research on medicinal plants. Most of them are involved in standardizing the herbal medicines and isolating active compounds. Few selected crops have been taken for improvement yet there is a need for research on quality planting materials for farmers, conservation of endangered species and to prevent exploitation of the natural resources. Reserpine (antihypertensive from rauwolfia) is an extremely valuable contribution from Ayurvedic systems. Curcumin (54) (anti-inflammatory from turmeric), withaferin A (55) (anti-inflammatory from ashwagandha), kutkoside (56) (hepatoprotective from kutki), andrographolide (57) (hepatoprotective from andrographis) and vasicine (58) (bronchodilator and expectorant from vasaka) are chemical entities with attractive scaffolds for drug discovery.

Controlled clinical trials are important to develop evidence for safety and efficacy. Results from clinical trials are encouraging (59), but lot more clinical research is required to establish validity of the system. Ayurvedic preparations have been successfully evaluated for treatment of bronchial asthma $(60,61)$, rheumatoid arthritis (62), ischaemic heart disease $(63,64)$. Piperine from pipali has come out as a bioenhancer in recent clinical evaluation $(65,66)$. Botanicals like Withania somnifera (67); Asparagus racemosus (68) have exhibited significant vaccine adjuvant activity in experimental systems, which have valuable applications in immunobiological industry. An IND application of Lupin Ltd. is in process and a US patent has been granted for development of herbal-based antipsoriatic composition containing Argemone mexicana (69). Standardized fraction of gugulipid from Commiphora wightii developed by CDRI has been marketed (Guglip ${ }^{\circledR}$, Cipla Ltd) for treating hyperlipidemia and atheriosclerosis (70). RRL Jammu has commercialized Boswellia serrata gum resin as NSAID (Non-Steroidal Anti-Inflammatory Drug) (Sallaki ${ }^{\circledR}$ Gufic). It is also hypolipidemic.

A multicentric study by the Indian Council of Medical Research (ICMR) showed promising results that a preparation from Pterocarpus marsupium was effective in reducing levels of blood glucose and glycosylated haemoglobin in patients with non-insulin-dependent diabetes mellitus (71). Analysis of most frequently used plant based therapies in Ayurvedic system revealed that $43 \%$ of them have been tested on humans while $62 \%$ have been the subject of one or more animal studies. Among these drugs having sufficient clinical data are guggul, brahmi, ashwagandha, amlaki, guduchi, kutki, shatavari and shunthi (72) Pharmacopoeia of India (1996) (73) covers few botanical monographs like clove, guggul, opium, mentha, senna, and ashwagandha. The Ayurvedic Pharmacopoeia of India gives monographs for 258 different Ayurvedic drugs. The standards mentioned are quite inadequate to build quality of the botanical materials (74). Indian Drug Manufacturers Association has published Indian Herbal Pharmacopoeia
(2002) (75) with 52 monographs on widely used medicinal plants growing in India where scientific data have been incorporated.

Harmonization and validation of the complex process of Ayurvedic therapeutics remain important. Novel efforts like Ayugenomics (76) aim to understand Ayurvedic concept of Prakruti from pharmcogenomics perspective to provide a base for human classification, diagnostics and customized medicine (77). Projects like AyuSoft (78) aim to develop intelligent and interactive software based on Ayurvedic classics as a decision support system. New analytical approaches like Herboprint (79) use three-dimensional HPLC and attempt to develop tools for activity-based standardization of botanicals.

\section{Supporting Systems}

Apart from the drug manufacturer, many other supporting industries play important roles in commerce of traditional medicine. The whole pipeline covers collectors and breeders, dealers of the plant materials, processing and manufacturing industry, practitioners of traditional medicine and finally the consumers. Presently, Indian systems of medicine use more than 1100 medicinal plants of which most are collected from the wild. More than 60 species are in great demand (80). The tribal belt of India is rich in these plants and the tribes mainly depend on this trade for livelihood. There are ample of opportunities for adulteration and contamination in the process. Thus, the adequate availability of quality raw materials free from adulterants at reasonable prices have become a big problem for industry and the demand is increasing every year. However, very few efforts have been made either by government or by industry to seriously study the supply and demand. Similar to China, India needs to follow GAPs to ensure the use of correct raw materials and cover the entire life cycle including the harvesting, processing, transportation and storage. Chinese government has developed more than 100 research units and encouraged private enterprises to build over 600 standard planting bases for herbs in great demand. Selection of the correct germplasm using modern DNA fingerprinting and chemoprofiling techniques is also a priority (81). India is emerging as a leader in generic drugs and is exporting them to developed countries. This is a result of adopting standard guidelines and GMPs. However, TIM has yet to capitalize on the quality herbal medicine where GAPs are.

New experiments are beginning to emerge on benefit sharing models for indigenous innovation. For example, Trichopus zeylanicus, found in the tropical forests of southwestern India was collected by the 'Kani' tribal people (a traditionally nomadic community from the forests of the Agasthyamalai hills in the Thiruvananthapuram district of Kerala, India). Scientists at the Tropical Botanic Garden and Research Institute (TBGRI) in Kerala discovered uses of this plant that are claimed to boost the immune system. Chemical and pharmacological investigations carried out initially at RRL, Jammu and later at TBGRI showed that the leaves of the plant 
contained various glycolipids and some other non-steroidal compounds with profound adaptogenic and immuneenhancing properties $(82,83)$. The fruits showed mainly antifatigue properties. TBGRI was successful in developing a scientifically validated and standardized herbal drug, based on the tribal lead (84). The drug was named 'Jeevani' and Arya Vaidya Pharmacy released it for commercial production in 1995 (85). TBGRI agreed to equally share the royalty with the tribal community. This experiment was acknowledged by UNDP by conferring a special award to the concerned scientists (86).

\section{Conclusion}

Numerous drugs have entered the international market through exploration of ethnopharmacology and traditional medicine. Progress in genomics and proteomics has opened new gateways in therapeutics and drug discovery and development. Better understanding of the human genome has helped in understanding scientific basis of individual variation. Drug targets have evolved during the last decade, but the industry remains target-rich and lead-poor trapped in the old mindset and strategies. TIM and TCM, carry many generations' observations that have well-organized and documented data (87). Although scientific studies have been done on a large number of Indian botanicals, a considerably smaller number of marketable drugs or phytochemical entities have entered the evidence-based therapeutics. China has successfully promoted its own therapies and drugs like ginseng, ma huang and gingko with scientific evidences acceptable for the global community. Approach of integrative medicine by selective incorporation of elements of TCM alongside the modern methods of diagnosis has achieved a great success in China (88).

India needs a clear policy for such integration without compromise on the strategies that are science-based. Efforts are needed to establish and validate pharmacoepidemiological evidence regarding safety and practice of Ayurvedic medicines (89). Pharmacoeconomic studies on TIM and TCM are rare, but can help in understanding cost-effectiveness and costbenefit of traditional medicine. In all such attempts, TCM examples would help India at various levels including policies, quality standards, integration practices, research models and the complementary integration where public health is kept at the central position. Both TIM and TCM are great traditions with strong philosophical basis and could play an important role in new therapies, drug discovery and development processes.

\section{Acknowledgments}

We thank Council for Scientific and Industrial Research, New Millennium Indian Technology Leadership Initiative Herbal Drug Development Group for discussions. Financial assistance from the University Grants Commission to one of the authors (D.W.) is also gratefully acknowledged.

\section{References}

1. Humber JM. The role of complementary and alternative medicine: accommodating pluralism. J Am Med Assoc 2002;288:1655-6.

2. Legal status of traditional medicine, complementary/alternative medicine: a worldwide reviewWorld Health Organization, Geneva, 2001.

3. Seidl PR. Pharmaceuticals from natural products: current trends. An Acad Bras Cienc 2002;74:145-50.

4. Available at http://www.ac-discovery.com.

5. Available at http://www.merlionpharma.com/index.html.

6. Jiang Y, Wang Y, Yan X. Chinese pharmaceutical companies: an emerging industry. Drug Discov Today 2000;6:610-2.

7. Dubey NK, Rajeshkumar, Tripathi P. Global promotion of herbal medicine: India's opportunity. Curr Sci 2004;86:37-41.

8. Mashelkar RA. Transforming India into the knowledge power. PDRC report, Government of India, 1999.

9. Patwardhan B, Chopra A, Vaidya ADB. Herbal remedies and the bias against Ayurveda. Curr Sci 2003;84:1165-6.

10. Fabricant DS, Farnsworth NR. The value of plants used in traditional medicine for drug discovery. Environ Health Perspect 2001;109:69-75.

11. Maggon K. Best selling human medicine 2002-2004. Drug Discov Today 2005;11:739-42

12. World Health Organization. Report of the inter-regional workshop on intellectual property rights in the context of traditional medicine, Bangkok, Thailand, Dec 6-8, 2000. http://www.who.int/medicines/ library/trm/who.edu.trm-2001-I/who-edutrm-2001-1.pdf.

13. Bodekar G, Kronenberg F. A public health agenda for complementary, alternative and traditional (indigenous) medicine. Am J Public Health 2002;92:1582-91.

14. De Smet PA. Herbal remedies. New Engl J Med 2002;347:2046-56.

15. Singh J, Singh AK, Khanuja SPS. Medicinal plants: India's opportunities. Pharma Bioworld 2003;1:59-66.

16. Handa SS. Indian efforts for quality control and standardization of herbal drugs/products. Proceedings of the 1 st joint workshop on quality control and standardization of traditional medicine-Indo-China experience, Jan 8-10, 2004.

17. A dream of globalizing the TCM market. Report of the Ministry of Commerce of the People's Republic of China, 2003.

18. Guidance for industry, M4: The CTD-quality questions answers/local issues, United States Food, Drug Administration 2004. Available at www.fda.gov/ohrms/dockets/dailys/03/Feb03/021103/8.

19. Cooper EL. CAM, eCAM, bioprospecting: the 21 st century pyramid. Evid Based Complement Alternat Med 2005;2:125-7.

20. Gavaghan H. Koop may set up new center for alternative medicine. Nature 1994;370:591.

21. Traditional Medicine Strategy 2002-2005. World Health Organization, Geneva, 2002.

22. Gibert TF. Reflections on traditional Chinese medicine and its pharmacopoeia. Ann Pharm Fr 1998;56:282-5.

23. Cheng JT. Review: drug therapy in Chinese traditional medicine. J Clin Pharmacol 2000;40:445-50.

24. Hankey A. CAM modalities can stimulate advances in theoretical biology. Evid Based Complement Alternat Med 2005;2:5-12.

25. Lad V. The human constitution. In: Ayurveda: The Science of Self-Healing. Wilmot: Lotus Press, 1985, 26-36.

26. Cardellina JH. Challenges and opportunities confronting the botanical dietary supplement industry. J Nat Prod 2002;65:1073-84.

27. Marccus DM, Grollman AP. Botanical medicines-the need for new regulations. New Engl J Med 2002;347:2073-6.

28. Quality Control Guidelines for Medicinal Plant MaterialsWorld Health Organization, Geneva, 1998; Available at http://www.who.int/medicines/ library/trm/medicinalplants/qualitycontrolmeth.pdf.

29. Draft guidelines: Guidance for Industry-Botanical drug productsUnited States Food, Drug Administration-CDER. 2000. Available at http://www.fda.gov/cder/guidance/4592fnl.htm.

30. EMEA Guidance on Herbal Products The European Agency for the Evaluation of Medicinal Products, London, 2001. Available at www. emea.eu.int/pdfs/human/qwp/281900en.pdf.

31. Warude D, Patwardhan B. Botanicals: quality and regulatory issues. J Sci Ind Res 2005;64:83-92.

32. Farnsworth NR. Relative safety of herbal medicines. Herbalgram 1993;29:36A-H. 
33. Saper RB, Kales SN, Paquin J, Burns MJ, Eisenberg DM, Davis RB, Phillips RS. Heavy metal content of ayurvedic herbal medicine products. J Am Med Assoc 2004;292:2868-73.

34. Ernst E. Toxic heavy metals and undeclared drugs in Asian herbal medicines. Trends Pharmacol Sci 2002;23:136-9.

35. Mukherjee PK. Herbal drugs-toxicity and regulations. In: Quality Control Herbal Drugs. New Delhi: Business Horizons, 2002, 39-87.

36. China's new quality control, functional foods and nutraceuticals, 2003. http://www.ffnuag.com/ASP/377/.

37. Sharma DC. India raises standards for traditional drugs. Lancet 2000; 356:231.

38. Patwardhan B. A method of treating musculoskeletal disease and a novel composition there of. US Patent 5494668, 1996.

39. The State Administration of traditional Chinese medicine of the People's Republic of China. Anthology of Policies, Laws and Regulations of the People's Republic of China on Traditional Chinese Medicine. Shangdong: Shangdong University, 1997.

40. Kumar S. India's government promotes traditional healing practices. Lancet 2000;335:1252.

41. Department of Indian Systems of Medicines and Homoeopathy. Government of India. Annual Report 1999-2000.

42. Barbara AJ, Ginger W. Turmeric patent overturned in legal victory. Herbalgram 1997;41:11.

43. Ganguli P. Patents and patent information in 1979 and 2004: a perspective from India. World Patent Inf 2004;26:61-2.

44. Goswami A, Barooch PK, Sandhu JS. Prospect of herbal drugs in the age of globalization-Indian scinario. J Sci Ind Res 2002;61:423-43.

45. Diwanay S, Gautam M, Patwardhan B. Cytoprotection and immunomodulation in cancer therapy. Curr Med Chem Anti-Canc Agents 2004;4: 479-90.

46. Patwardhan B, Gautam M. Botanical immunodrugs: scope and opportunities. Drug Discov Today 2005;7:495-502.

47. Normile D. The new face of traditional Chinese medicine. Science 2003;299:188-90.

48. The Pharmacopoeia of Peoples Republic of China, Pharmacopoeia Commission of the Ministry of Public Health, China, 2002.

49. Tang JL, Zhan SY, Ernst E. Review of randomized controlled trials of traditional Chinese medicine. Br Med J 1999;319:160-1.

50. Cao Y, Shi Y, Zheng Y, Shi M, Lo SK. Blood-nourishing and hardsoftening capsule costs less in the management of osteoarthritic knee pain: a randomized controlled trial. Evid Based Complement Alternat Med 2005;2:363-8.

51. Nelson R. FDA issues alert on ephedra supplements in the USA. Lancet 2004;363:135.

52. Fong KCS, Kinnear PE. Gingko biloba and retrobulbar hemorrhage following peribulbar local anesthetic injection for cataract surgery. Postgrad Med J 2003;79:531-2.

53. Patwardhan B, Vaidya ADB, Chorghade M. Ayurveda and natural product drug discovery. Curr Sci 2004;86:789-99.

54. Ammon HP, Safayhi H, Mack T, Sabieraj J. Mechanism of antiinflammatory actions of curcumin and boswellic acids. J Ethnopharmacol 1993:38:113-9.

55. Jayaprakasam B, Muraleedharan GN. Cyclooxygenase-2 enzyme inhibitory withanolides from Withania somnifera leaves. Tetrahydron 2003;59: 841-9.

56. Dwivedi Y, Rastogi R, Garg NK, Dhawan BN. Picroliv and its components kutkoside and picroside I protect liver against galactosamine-induced damage in rats. Pharmacol Toxicol 1992;71: 383-7.

57. Visen PK, Shukla B, Patnaik GK, Dhawan BN. Andrographolide protects rat hepatocytes against paracetamol-induced damage. J Ethnopharmacol 1993;40:131-6.

58. Johri RK, Zutshi U. Mechanism of action of 6,7,8,9,10,12-hexahydroazepino-[2,1-b]quinazolin-12-one-(RLX) — a novel bronchodilator. Indian $J$ Physiol Pharmacol 2000;44:75-81.

59. Bhatt AD. Clinical trials of Ayurvedic medicine: myths, realities and challenges. J Assoc Physicians India 2001;49:558-62.

60. Sekhar AV, Gandhi DN, Rao NM, Rawal UD. An experimental and clinical evaluation of anti-asthmatic potentialities of Devadaru compound (DC). Indian J Physiol Pharmacol 2003;47:101-7.

61. Gupta I, Gupta V, Parihar A, Gupta S, Ludtke R, Safayhi H. Effects of Boswellia serrata gum resin in patients with bronchial asthma: results of a double-blind, placebo-controlled, 6-week clinical study. Eur J Med Res 1998:3:511-4.
62. Chopra A, Lavin P, Patwardhan B, Chitre D. Randomized double blind trial of an ayurvedic plant derived formulation for treatment of rheumatoid arthritis. J Rheumatol 2000;27:1365-72.

63. Gupta R, Singhal S, Goyle A, Sharma VN. Antioxidant and hypocholesterolaemic effects of Terminalia arjuna tree-bark powder: a randomized placebo-controlled trial. J Assoc Physicians India 2000;49: $231-5$.

64. Kumar PU, Adhikari P, Pereira P, Bhat P. Safety and efficacy of Hartone in stable angina pectoris-an open comparative trial. $J$ Assoc Physicians India 1999;47:685-9.

65. Majeed M, Badmaev V, Rajendran R. Use of piperine as a bioavailability enhancer. US Patent 5972382, Sabinsa Corporation USA, 1999.

66. Atal CK, Dubey RK, Singh J. Biochemical basis of enhanced drug availability by piperine: evidence that piperine is a potent inhibitor of drug metabolism. J Pharmacol Exp Ther 1985;232:258-62.

67. Gautam M, Diwanay SS, Gairola S, Shinde YS, Jadhav SS, Patwardhan BK. Immune response modulation to DPT vaccine by aqueous extract of Withania somnifera in experimental system. Int Immunopharmacol 2004;4:841-9.

68. Gautam M, Diwanay S, Gairola S, Shinde Y, Patki P, Patwardhan B. Immunoadjuvant potential of Asparagus racemosus aqueous extract in experimental system. $J$ Ethnopharmacol 2004;91: $251-5$.

69. Arora S, Gupta L, Srivastava V, Sanganabhatla N, Sara DB. Herbal composition for treating various disorders including psoriasis, a process for preparation thereof and method for treatment of such disorders. US Patent 20030194456, 2003.

70. Singh K, Chandar R, Kapoor NK. Guggulsterone, a potent hypolipidaemic, prevents oxidation of low-density lipoprotein. Phytother Res 1998;11:291-4.

71. Indian Council of Medical Research. Flexible dose open trail of Vijayasar in cases of newly diagnosed non-insulin dependent diabetes mellitus. Indian J Med Res 1998;108:24-9.

72. Khan S, Balick MJ. Therapeutic plants of ayurveda: a review of selected clinical and other studies for 166 species. J Altern Complement Med 2001;7:405-515.

73. The Pharmacopoeia of India. Controller of Publication, Government of India, 1996.

74. Raina MK. Quality control of herbal and herbo-mineral formulations. Indian J Nat Prod 2003;19:11-5.

75. The Indian Herbal Pharmacopoeia. Mumbai, Indian Drug Manufacturer's Association, 2002.

76. Patwardhan B. Ayugenomics ${ }^{\circledR}$ : integration for customized medicine. Indian J Nat Prod 2003;19:16-23.

77. Patwardhan B, Joshi K, Chopra A. Classification of human population based on HLA gene polymorphism and the concept of Prakriti in Ayurveda. J Altern Complement Med 2005;11:349-53.

78. AyuSoft-a decision support system for Ayurveda. C-DAC, (Center for Development of Advance Computing) Pune. Project sponsored by Ministry of Communication and Information Technology, Government of India, 2004. www.edac.in.

79. VijayaKumar D, Raghavan KV. Novel chromatographic fingerprinting method for standardization of single medicines and formulations. Indian Institute of Chemical Technology, Hyderabad, WO 0246739-EP2 0000991 991-263397CSIR G01N30-88, 2002.

80. Farooqi AA, Sreeramu BS. History, importance, present status and future prospects of medicinal crops. In: Cultivation of Medicinal and Aromatic Crops. Hyderabad: Universities press, 2001, 1-19.

81. Wo Jizhou Thinking about the situation of research on GAP in China. Proceedings of the 1st joint workshop on quality control and standardization of traditional medicine-Indo-China experience, Jan 810, 2004.

82. Subramoniam A, Evans DA, Rajasekharan S, Pushpangadan P. Effect of Trichopus zeylanicus Gaertn. (active fraction) on phagocytosis by peritoneal macrophages and humoral immune response in mice. Indian J Pharmacol 2000;32:221-5.

83. Susan C, Sethuraman MG, George V, Pushpangadan P. Phytochemical constituents of Trichopus zeylanicus ssp. Travancoricus. J Med Aromatic Plant Sci 2002;24:703-6.

84. Pushpangadan P. Traditional knowledge \& folklore-A benefitsharing model experimented in India. International conference of commission on intellectual property rights organized by Royal Society, London, Feb 21-22, 2002. 
85. Pushpangadan P. Biodiversity and emerging benefit-sharing arrangements-challenges and opportunities for India. Proc Indian Natl Sci Acad 2002;B68:297-311.

86. Available at http://www.undp.org/biodiversity/biodiversitycd/practice India.htm\#EI.

87. Patwardhan B. Ayurveda: the 'designer' medicine: a review of ethno pharmacology and bioprospecting research. Indian Drugs 2000;37:213-27.
88. Faass N. Integrating Complementary Medicine into Health Systems. Gaithersburg: Aspen Publications, 2001.

89. Vaidya RA, Vaidya ADB, Patwardhan B, Tillu G, Rao Y. Ayurvedic pharmacoepidemiology: a proposed new discipline. J Assoc Physicians India 2003;51:528.

Received June 13, 2005; accepted October 7, 2005 


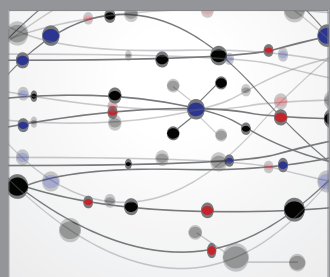

The Scientific World Journal
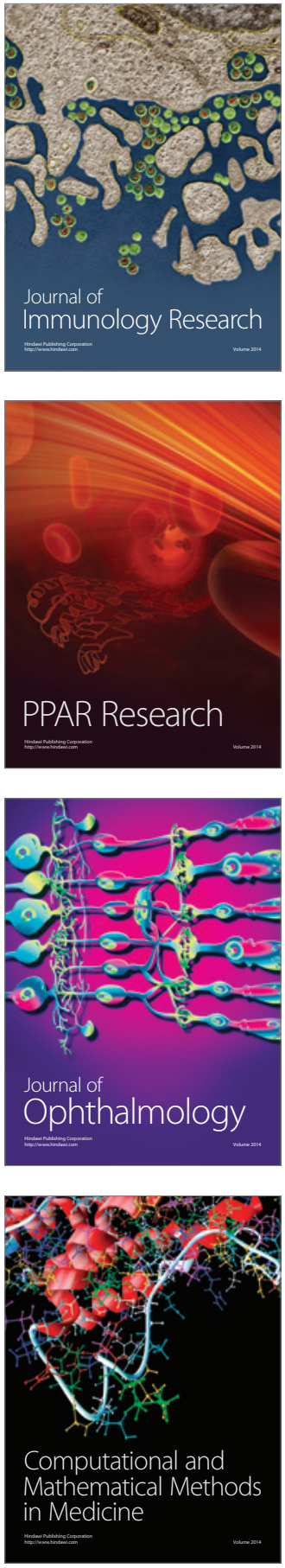

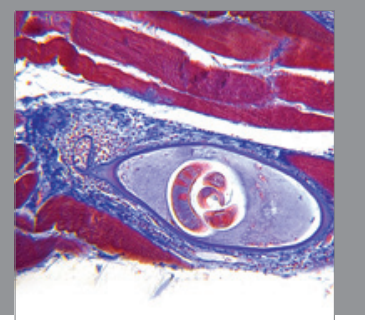

Gastroenterology

Research and Practice
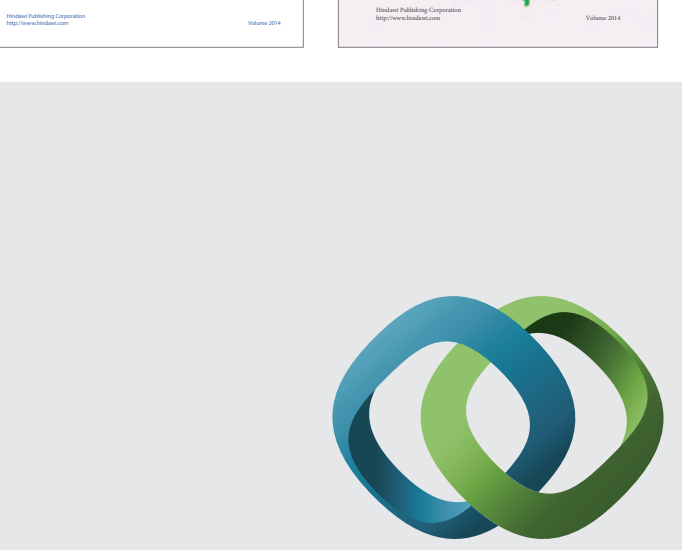

\section{Hindawi}

Submit your manuscripts at

http://www.hindawi.com
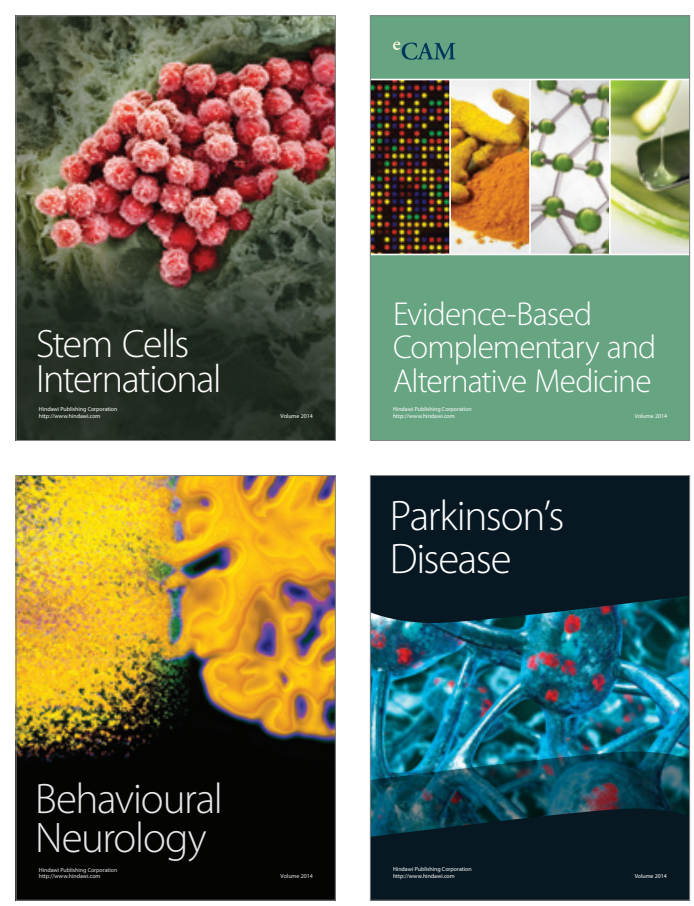

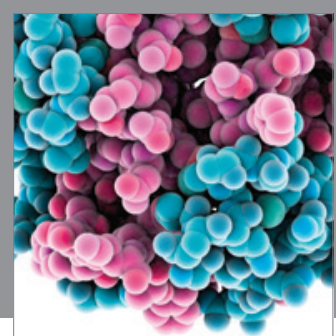

Journal of
Diabetes Research

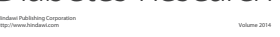

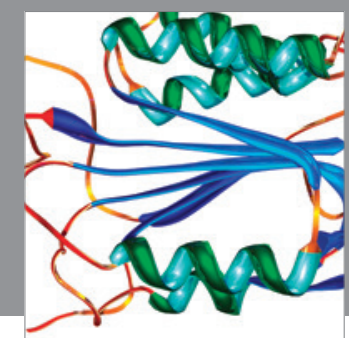

Disease Markers
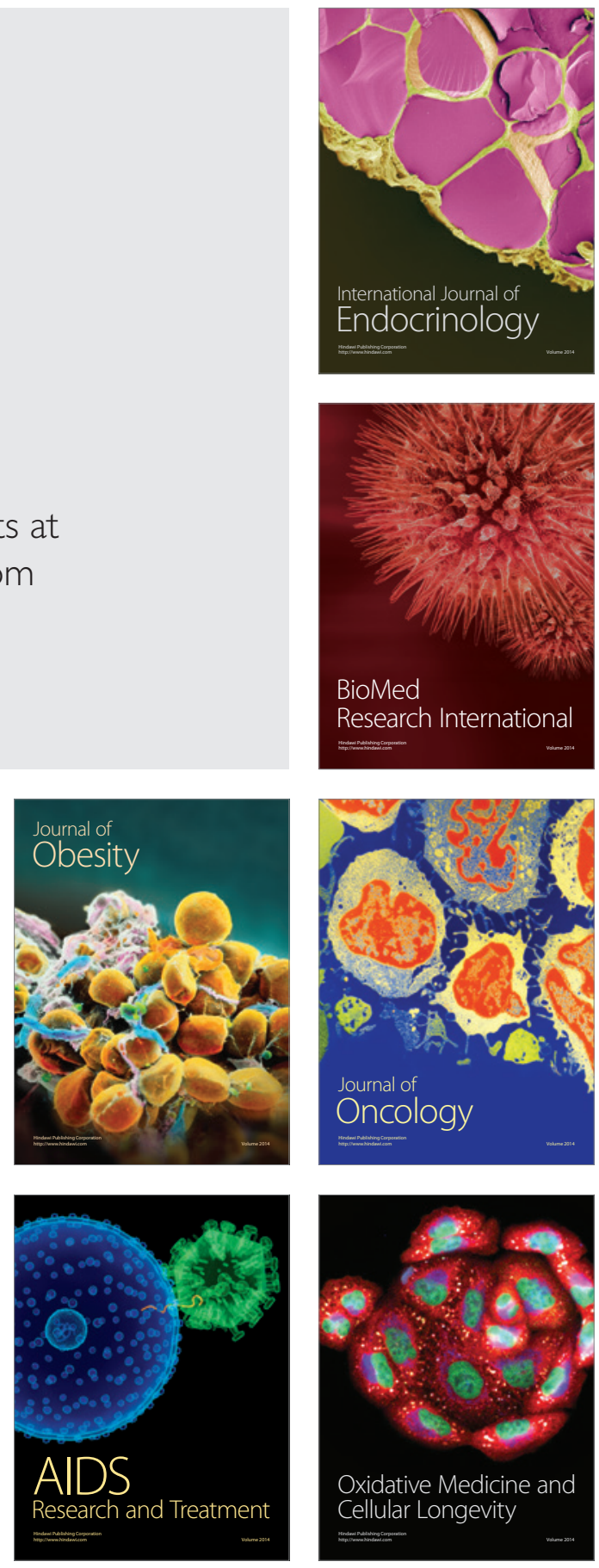